\title{
Fluoroquinolone susceptibility in Pseudomonas aeruginosa isolates from dogs - comparing disk diffusion and microdilution methods
}

\author{
Selma Pintarić1 ${ }^{*}$, Krešimir Matanović ${ }^{2}$, and Branka Šeol Martinec ${ }^{1}$ \\ ${ }^{l}$ Department of Microbiology and Infectious Diseases with Clinic, Faculty of Veterinary Medicine, \\ University of Zagreb, Zagreb, Croatia \\ ${ }^{2}$ Department for Biology and Pathology of Fish and Bees, Faculty of Veterinary Medicine, \\ University of Zagreb, Zagreb, Croatia
}

\begin{abstract}
PINTARIĆ, S., K. MATANOVIĆ, B. ŠEOL MARTINEC: Fluoroquinolone susceptibility in Pseudomonas aeruginosa isolates from dogs - comparing disk diffusion and microdilution methods. Vet. arhiv 87, 291-300, 2017.
\end{abstract}

\section{ABSTRACT}

Pseudomonas aeruginosa has been determined to be the distinct cause of a number of different infections in both humans and animals. Apart from its high intrinsic resistance, which makes it difficult to treat, it also has a great capacity to acquire further resistance mechanisms. These mechanisms can be present simultaneously in one cell, conferring a multiresistant phenotype. Taking into account that the known risk factor for selection of resistant strains is excessive and inappropriate drug use, especially fluoroquinolones, the aim of this study was to determine the susceptibility of $P$. aeruginosa isolates to these antibacterial agents. The susceptibility of 90 canine isolates was determined by disk diffusion susceptibility test and the broth microdilution method. Both methods showed that isolates were significantly more sensitive to ciprofloxacin than to marbofloxacin or enrofloxacin, and more sensitive to marbofloxacin than to enrofloxacin. The results of microdilution and disk diffusion testing were in $98.9 \%$ agreement for ciprofloxacin and in $91.1 \%$ agreement for marbofloxacin, with no statistically significant difference between the two methods $(\mathrm{P}>0.05)$ for these two antibiotics. For enrofloxacin, the results of microdilution and disk diffusion testing were in $76.6 \%$ agreement, with a statistically significant disagreement between the two methods $(\mathrm{P}<0.05)$. In 16 cases, the disk diffusion test overestimated the number of strains susceptible to enrofloxacin compared with the microdilution test. These results suggest that for $P$. aeruginosa infections in dogs, therapy using enrofloxacin, based on the results of disk diffusion testing, may lead to ineffective treatment and could contribute to selection of resistant and multiresistant strains.

Key words: Pseudomonas aeruginosa, dog, fluoroquinolones, antimicrobial susceptibility, disk diffusion, broth microdilution

\footnotetext{
*Corresponding author:

Selma Pintarić, PhD, DVM, Department of Microbiology and Infectious Diseases with Clinic, Faculty of Veterinary Medicine, University of Zagreb, Heinzelova 55, 10000 Zagreb, Croatia, Phone: +385 12390 212; Fax: +385 12390208 ; E-mail: selma.pintaric@vef.hr
} 
S. Pintarić et al.: Fluoroquinolone susceptibility in Pseudomonas aeruginosa isolates from dogs

\section{Introduction}

Pseudomonas aeruginosa causes opportunistic infections in both humans and animals. In dogs, this bacterium has been recognized as the distinct cause of infections such as: otitis externa, urinary tract infections, conjunctivitis, pneumonia, endocarditis and dermatitis (MARKEY et al., 2013).

Treatment of $P$. aeruginosa infections is difficult because of its high intrinsic resistance to many commonly used antibiotics, such as penicillins, first and second generation cephalosporins, macrolides and chloramphenicol, some aminoglycosides, some fluoroquinolones, tetracyclines and sulfonamides (LIVERMORE et al., 2001). Therefore, the choice of antibiotics that can be used to treat $P$. aeruginosa infections is very narrow, especially in veterinary medicine (GIGUÈRE et al., 2013). Furthermore, apart from its high intrinsic resistance, $P$. aeruginosa also has a great capacity to acquire further resistance mechanisms, which include: efflux pump expression, decreased permeability, target site alterations and production of antibiotic-hydrolyzing enzymes. These mechanisms can be present simultaneously in one cell, conferring a multiresistant phenotype. Treatment of infections caused by such microorganisms is very challenging (STRATEVA and YORDANOV, 2009).

The known risk factors for selection of resistant and multiresistant strains are excessive drug use and inappropriate dosage regimens without previous antimicrobial susceptibility testing. This is especially true for fluoroquinolones as they are known as antimicrobials with a high tendency to select resistant bacteria if dosed inappropriately (GIGUÈRE et al., 2013).

A precise dose of a certain antimicrobial required to inhibit growth of a pathogen is determined on the basis of the minimum inhibitory concentration (MIC). According to recommendations by the Clinical and Laboratory Standards Institute (CLSI), $P$. aeruginosa isolates with enrofloxacin MIC of $\leq 0.5 \mu \mathrm{g} / \mathrm{mL}$ are reported as susceptible, while intermediately susceptible strains have MICs between 1 and $2 \mu \mathrm{g} / \mathrm{mL}$ (ANONYMOUS, 2013b). However, COLE et al. (2008) state that enrofloxacin should be dosed at $20 \mathrm{mg} / \mathrm{kg}$ once a day (high end of the enrofloxacin dose range) for the treatment of infections caused by bacteria with a MIC of $0.51-0.64 \mu \mathrm{g} / \mathrm{mL}$. Considering this, all $P$. aeruginosa isolates estimated as intermediately susceptible to enrofloxacin should be reported as resistant. Besides, without information about the MIC, clinicians cannot make an appropriate decision about the dosage regimen. In the bacteriological laboratory of the Faculty of Veterinary Medicine in Croatia disk diffusion is the method routinely used for susceptibility testing, and the question is whether this method is accurate enough to achieve appropriate therapeutic results if maximum doses of enrofloxacin are used for all P. aeruginosa strains estimated as susceptible. 


\section{S. Pintarić et al.: Fluoroquinolone susceptibility in Pseudomonas aeruginosa isolates from dogs}

The aim of this study was to determine the susceptibility of $P$. aeruginosa to enrofloxacin and marbofloxacin as fluoroquinolones registered for use in veterinary medicine in Croatia, and susceptibility to ciprofloxacin, which is frequently used off-label in veterinary medicine. Further, our goal was to evaluate the validity of reporting results of disk diffusion testing for chosen fluoroquinolones.

\section{Materials and methods}

Ninety P. aeruginosa strains isolated from dogs in the bacteriological laboratory at the Department for Microbiology and Infectious Diseases with Clinic of the Faculty of Veterinary Medicine, University of Zagreb, in the period from December 2008 to December 2009, were used in this study. The majority of isolates were recovered from the ear canal $(62.2 \%)$ and skin $(13.3 \%)$. The rest were obtained from the throat $(5.6 \%)$, nostrils $(4.5 \%)$, conjunctival sac $(4.5 \%)$, vagina $(3.3 \%)$, anal sac $(2.2 \%)$, foreskin $(1.1 \%)$, bone fracture (1.1\%), urine (1.1\%) and feces (1.1\%). Identification of P. aeruginosa was carried out according to the procedure described by MARKEY et al. (2013). Antimicrobial susceptibility to enrofloxacin, marbofloxacin and ciprofloxacin was determined by the disk diffusion and broth microdilution methods, according to the CLSI recommendations (ANONYMOUS, 2013a). Both susceptibility tests were performed from the same bacterial inoculum, adjusted to turbidity of $0.5 \mathrm{McF}$ arland. The antimicrobial concentration range for microdilution testing was 0.25 to $256 \mu \mathrm{g} / \mathrm{mL}$ for enrofloxacin (Krka, Slovenia), 0.125 to $128 \mu \mathrm{g} / \mathrm{mL}$ for marbofloxacin (Vétoquinol, France) and 0.06 to $64 \mu \mathrm{g} / \mathrm{mL}$ for ciprofloxacin (Salutas Pharma GmbH, Germany). Disk diffusion testing was performed with $5 \mu \mathrm{g}$ disks of enrofloxacin (Bio-Rad, USA), marbofloxacin (Bio-Rad, USA) and ciprofloxacin (bioMerieux, France).

Inhibition zone diameters and minimum inhibitory concentrations were interpreted according to the criteria recommended by the CLSI in documents VET01-S2 and M100-S24, and they are summarized in Tables 1 and 2 (ANONYMOUS, 2013b; ANONYMOUS, 2014). Pseudomonas aeruginosa ATCC 27853 was included in the study as a control strain.

Statistical analysis was performed using Statistica v12.5. Software (StatSoft Inc.). Basic data processing was performed by standard procedures of descriptive statistics. Significance of differences between the three fluoroquinolones was determined by the Wilcoxon matched pairs test, with statistical significance set at $\mathrm{P}<0.05$. The differences between the two methods were analyzed using separate Wilcoxon matched pairs tests for each antibiotic included in the research. According to CLSI document M37-A3, discrepancy rates were classified into three categories: very major discrepancy (falsesusceptible disk diffusion test result), major discrepancy (false-resistant disk diffusion test 
S. Pintarić et al.: Fluoroquinolone susceptibility in Pseudomonas aeruginosa isolates from dogs

result) and minor discrepancy (difference in one interpretation category) (ANONYMOUS, 2008).

\section{Results}

Disk diffusion antimicrobial susceptibility testing showed that among the tested fluoroquinolones, ciprofloxacin was the most active compound, with $95.6 \%$ sensitive strains. The least active was enrofloxacin, with 25 (27.8\%) susceptible and $50(55.6 \%)$ intermediately susceptible isolates. The results of disk diffusion testing and the criteria used for interpretation of inhibition zone diameters are summarized in Table 1. Distributions of inhibition zone diameters for each tested fluoroquinolone are summarized in Fig 1.

Table 1. Zone diameter interpretation standards and results of disk diffusion testing for 90 Pseudomonas aeruginosa isolates

\begin{tabular}{|c|c|c|c|c|c|c|}
\hline \multirow[b]{2}{*}{$\begin{array}{l}\text { Antimicrobial } \\
\text { agent }\end{array}$} & \multicolumn{3}{|c|}{$\begin{array}{l}\text { Disk diffusion testing } \\
\text { zone diameter breakpoints }(\mathrm{mm})\end{array}$} & \multicolumn{3}{|c|}{ Results of disk diffusion testing } \\
\hline & $\geq \mathrm{S}$ & I & $\leq \mathrm{R}$ & $\begin{array}{l}\text { Susceptible } \\
\text { strains }(\%)\end{array}$ & $\begin{array}{l}\text { Intermediate } \\
\text { strains }(\%)\end{array}$ & $\begin{array}{l}\text { Resistant } \\
\text { strains (\%) }\end{array}$ \\
\hline Enrofloxacin & 23 & $17-22$ & 16 & $25(27.8)$ & $50(55.6)$ & $15(16.7)$ \\
\hline Marbofloxacin & 20 & $15-19$ & 14 & $78(86.7)$ & $7(7.8)$ & $5(5.6)$ \\
\hline Ciprofloxacin & 21 & $16-20$ & 15 & $86(95.6)$ & $2(2.2)$ & $2(2.2)$ \\
\hline
\end{tabular}

$\mathrm{S}=$ susceptible, $\mathrm{I}=$ intermediately susceptible, $\mathrm{R}=$ resistant

Table 2. MIC Interpretive Standards and results of microdilution testing for 90 Pseudomonas aeruginosa isolates

\begin{tabular}{|l|c|c|c|c|c|c|c|c|}
\hline & \multicolumn{3}{|c|}{$\begin{array}{c}\text { MIC breakpoints } \\
(\mu \mathrm{g} / \mathrm{mL})\end{array}$} & \multicolumn{5}{|c|}{ Results of microdilution testing } \\
\hline $\begin{array}{l}\text { Antimicrobial } \\
\text { agent }\end{array}$ & $\leq \mathrm{S}$ & $\mathrm{I}$ & $\geq \mathrm{R}$ & $\begin{array}{c}\text { Susceptible } \\
\text { strains (\%) }\end{array}$ & $\begin{array}{c}\text { Intermediate } \\
\text { strains (\%) }\end{array}$ & $\begin{array}{c}\text { Resistant } \\
\text { strains (\%) }\end{array}$ & $\mathrm{MIC}_{50}$ & $\mathrm{MIC}_{90}$ \\
\hline Enrofloxacin & 0.5 & $1-2$ & 4 & $8(8.9)$ & $68(75.6)$ & $14(15.6)$ & 1 & 4 \\
\hline Marbofloxacin & 1 & 2 & 4 & $73(81.1)$ & $9(10.0)$ & $8(8.9)$ & 1 & 2 \\
\hline Ciprofloxacin & 1 & 2 & 4 & $85(94.4)$ & $3(3.3)$ & $2(2.2)$ & 0.25 & 0.5 \\
\hline
\end{tabular}

$\mathrm{MIC}=$ minimum inhibitory concentration, $\mathrm{MIC}_{50}=\mathrm{MIC}$ that inhibited at least $50 \%$ of the isolates, $\mathrm{MIC}=\mathrm{MIC}_{90}$ that inhibited at least $90 \%$ of the isolates. $\mathrm{S}=$ susceptible, $\mathrm{I}=$ intermediately susceptible, $\mathrm{R}=$ resistant

From the results of disk diffusion testing, isolates were significantly more sensitive to ciprofloxacin than to marbofloxacin or enrofloxacin $(\mathrm{P}<0.05)$. Furthermore, the isolates were significantly more susceptible to marbofloxacin than to enrofloxacin $(\mathrm{P}<0.05)$.

From the results of microdilution testing, the isolates were also significantly more susceptible to ciprofloxacin than to marbofloxacin or enrofloxacin $(\mathrm{P}<0.05)$ and were significantly more susceptible to marbofloxacin than to enrofloxacin $(\mathrm{P}<0.05)$. There were 85 strains (94.4\%) sensitive to ciprofloxacin with MICs between 0.06 and 
$1 \mu \mathrm{g} / \mathrm{mL}$. Seventy-three strains (81.1\%) showed susceptibility to marbofloxacin, with slightly higher MICs, mostly between 0.25 and $1 \mu \mathrm{g} / \mathrm{mL}$. With eight (8.9\%) susceptible strains, enrofloxacin was the least active compound. The antimicrobial activities of the three fluoroquinolones against $P$. aeruginosa strains and their $\mathrm{MIC}_{50}$ and $\mathrm{MIC}_{90}$ values are summarized in Table 2. Distributions of MICs for each tested fluoroquinolone are summarized in Fig, 1.

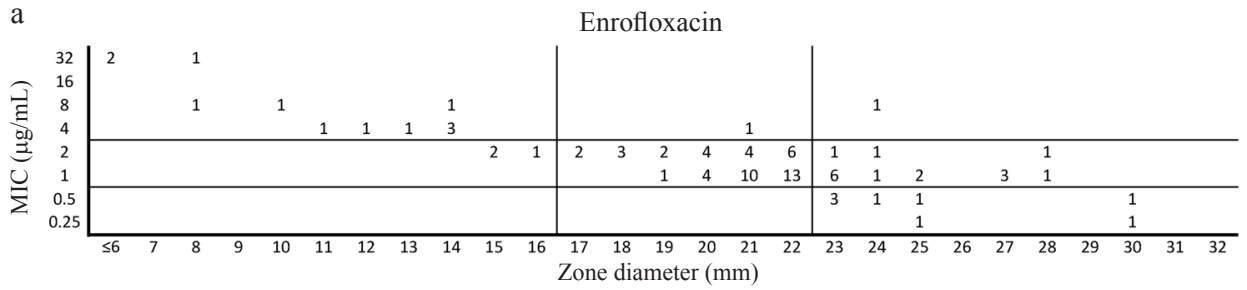

b
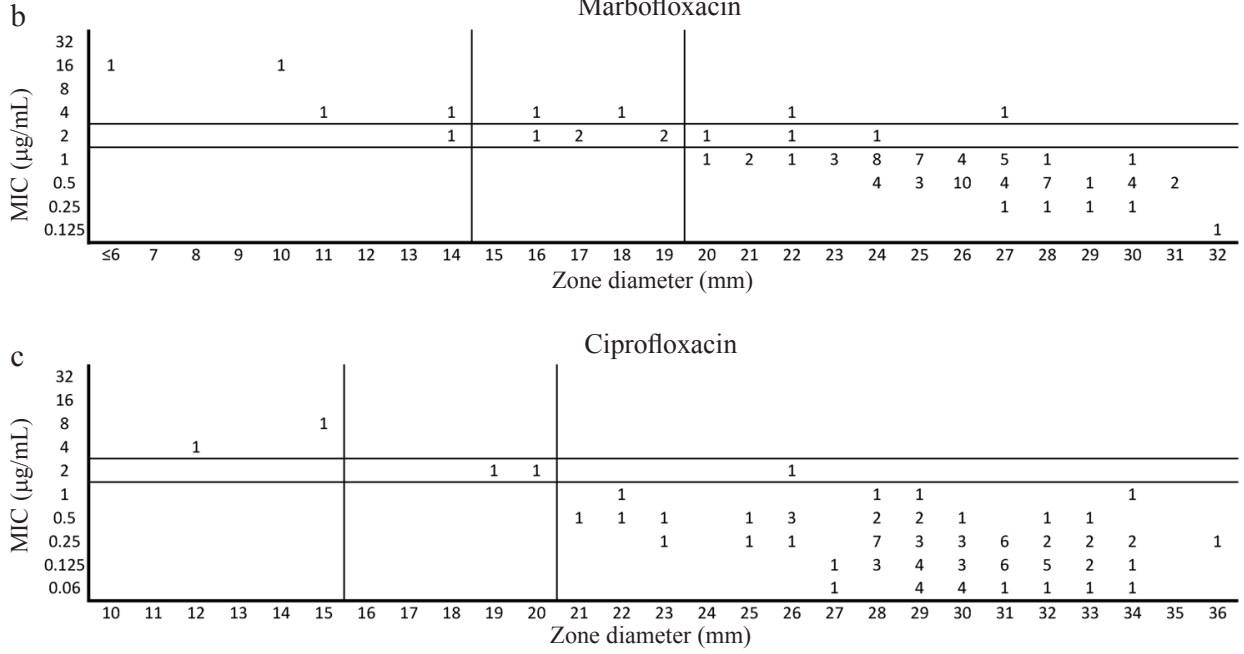

Fig. 1. Scattergrams of enrofloxacin (a), marbofloxacin (b) and ciprofloxacin (c) MICs versus disk diffusion zone diameters for 90 Pseudomonas aeruginosa isolates. Numbers represent the numbers of isolates. The horizontal and vertical lines represent MIC and disk diffusion breakpoints, respectively.

For ciprofloxacin, the results of microdilution and disk diffusion testing were in 98.9\% agreement, with no statistically significant disagreement between the two methods $(\mathrm{P}>0.05)$. There was only one minor error with one strain showing susceptibility on disk diffusion testing but intermediate susceptibility on microdilution testing. 
There was no statistically significant disagreement between the results of the two methods for marbofloxacin, and the results were in $91.1 \%$ agreement. This comparison showed six minor errors and two very major errors.

For enrofloxacin, the results of microdilution and disk diffusion testing were in $76.6 \%$ agreement ( 69 isolates showed the same result by both methods) with a statistically significant disagreement between the two methods $(\mathrm{P}<0.05)$. Comparison identified 20 $(22.2 \%)$ minor errors and one (1.1\%) very major error (Fig. 1).

\section{Discussion}

In this study we carried out a comparison of the results obtained by two methods, disk diffusion and microdilution susceptibility testing. There were no statistically significant differences between those two methods for marbofloxacin and ciprofloxacin. On the other hand, comparison showed a statistically significant disagreement between the results obtained with microdilution and disk diffusion testing for enrofloxacin. Only $76.6 \%$ of results were in agreement, and most of the disagreements were due to the disk diffusion test overestimating the number of susceptible strains compared to microdilution testing. Out of 20 minor errors, 16 errors were isolates estimated as susceptible by the disk diffusion method but intermediately susceptible by microdilution. Similar results were found by McKAY et al. (2007), where $87 \%$ agreement between microdilution and disk diffusion testing was reported for marbofloxacin, with no statistically significant disagreement between the two methods. For enrofloxacin, authors reported that the results of the two methods were in $74 \%$ agreement, with a statistically significant difference between them. In 20 instances, disk diffusion testing overestimated the number of enrofloxacin-susceptible strains compared with microdilution. On the basis of these results, the authors concluded that the use of disk diffusion testing to evaluate the enrofloxacin susceptibility of $P$. aeruginosa strains may result in inappropriate and ineffective therapy (McKAY et al., 2007). According to COLE et al. (2008), for bacteria with a minimum inhibitory concentration of $0.51-0.64 \mu \mathrm{g} / \mathrm{mL}$, enrofloxacin should be dosed at $20 \mathrm{mg} / \mathrm{kg}$ (high end of the enrofloxacin dose range). On this basis, all intermediately susceptible isolates should be considered resistant, since appropriate tissue levels cannot be obtained even with a maximum dose of enrofloxacin. On the basis of the results of disk diffusion testing, it is impossible to calculate an accurate and appropriate dose of enrofloxacin for therapy since there is no information about the MIC. In addition, our study showed that most isolates interpreted as susceptible by disk diffusion showed MICs higher than $0.5 \mu \mathrm{g} / \mathrm{mL}$ on microdilution testing. For such isolates even a maximum dose of enrofloxacin would not be sufficient and could lead to therapeutic failure. Furthermore, the results of microdilution testing showed that only eight (8.9\%) strains were susceptible to enrofloxacin, with six of them having a MIC of $0.5 \mu \mathrm{g} / \mathrm{mL}$. These results suggest that 


\section{S. Pintarić et al.: Fluoroquinolone susceptibility in Pseudomonas aeruginosa isolates from dogs}

in most cases of $P$. aeruginosa infections enrofloxacin should be used at its maximum dose. In Croatia, enrofloxacin is licensed for veterinary use under several trade names, with a recommended dose of 2.5 to $5 \mathrm{mg} / \mathrm{kg}$ body weight in dogs. There is no additional data about the possibility of increasing the dose to $20 \mathrm{mg} / \mathrm{kg}$ for treating $P$. aeruginosa infections. We assume that most clinicians comply with the dosage guidelines in drug labels. This led us to the question about the validity of reporting $P$. aeruginosa strains as susceptible based on disk diffusion testing, and emphasizes the need for reviewing drug labels for enrofloxacin in Croatia, regarding dosage and duration of therapy.

Compared to this study, a lower susceptibility rate was reported in Croatia a few years ago (MEKIĆ et al., 2011) with one (1.1\%) strain susceptible to enrofloxacin. In that study susceptibility testing was performed by Etest ${ }^{\circledR}$. Besides the difference in the methods used, there is a difference between the origins of the isolates. Isolates included in the study from 2011 were all collected from the ears of dogs with otitis externa, and it is well known that otic isolates tend to show higher resistance rates to several antimicrobials, including enrofloxacin and other fluoroquinolones (PETERSEN et al., 2002; WILDERMUTH et al., 2007; HARADA et al., 2012). Nevertheless, the sensitivity rate to enrofloxacin found in this study was still lower than sensitivity rates observed in other studies, where susceptibility ranged between 16\% and 51\% (COLOMBINI et al., 2000; MARTIN BARRASA et al., 2000; McKAY et al., 2007; WERCKENTHIN et al., 2007).

On the other hand, the resistance to marbofloxacin found in this study is lower than the resistance rates of between $25 \%$ and $49 \%$ recorded in other studies (McKAY et al., 2007; RUBIN et al, 2008; MÜLLER and HOM, 2009). The main reason for this is probably the fact that marbofloxacin is registered in Croatia only for topical treatment of otitis externa. On the other hand, enrofloxacin is registered for systemic use, and is prescribed not only for otitis externa but also for infections of other body sites. Therefore, obviously, enrofloxacin is used more often than marbofloxacin.

Resistance to ciprofloxacin has not significantly changed since the first study was conducted in Croatia in 2002, when $93.4 \%$ of isolates were susceptible and 3.8\% were resistant to ciprofloxacin (ŠEOL et al., 2002). The resistance rate reported in the Croatian study from 2011 (MEKIĆ et al., 2011) was higher (8.7\%) but the main reason for that was the difference in the origin of the isolates. A similar difference in susceptibility to ciprofloxacin between isolates of different origin had already been reported by PETERSEN et al. (2002). They detected $95.2 \%$ of skin isolates and $92.9 \%$ of ear isolates that were susceptible to ciprofloxacin.

In the present study, all the isolates that were resistant to ciprofloxacin were also resistant to enrofloxacin and marbofloxacin, and there were significantly more ciprofloxacinsusceptible strains than those susceptible to enrofloxacin and/or marbofloxacin. These 
S. Pintarić et al.: Fluoroquinolone susceptibility in Pseudomonas aeruginosa isolates from dogs

findings were expected and are in agreement with the results of other studies (RIDDLE et al., 2000; TEJEDOR et al., 2003; MEKIĆ et al., 2011).

In conclusion, comparison of the two methods showed that disk diffusion testing is not a method of choice for testing the susceptibility of $P$. aeruginosa isolates to enrofloxacin. Moreover, due to the high percentage of resistant and intermediately susceptible isolates, with MICs above $0.5 \mu \mathrm{g} / \mathrm{mL}$, enrofloxacin is not a good choice for treating P. aeruginosa infections. For such isolates even the maximum recommended dose of enrofloxacin would not be high enough to achieve appropriate tissue levels (COLE et al., 2008). On the basis of the results obtained we consider marbofloxacin and ciprofloxacin as the drugs of choice among fluoroquinolones against $P$. aeruginosa. In the light of all of the above, our results emphasize the need for the revision of drug labels for enrofloxacin in Croatia.

\section{References}

ANONYMOUS (2008): Development of In vitro Susceptibility Testing Criteria and Quality Control Parameters for Veterinary Antimicrobial Agents; Approved Guideline-Third Edition. CLSI document M37-A3. Wayne, PA: Clinical and Laboratory Standards Institute; 2008.

ANONYMOUS (2013a): Performance Standards for Antimicrobial Disk and Dilution Susceptibility Tests for Bacteria Isolated From Animals; Approved Standard-Fourth Edition. CLSI document VET01-A4. Wayne, PA: Clinical and Laboratory Standards Institute; 2013.

ANONYMOUS (2013b): Performance Standards for Antimicrobial Disk and Dilution Susceptibility Tests for Bacteria Isolated From Animals; Second Informational Supplement. CLSI document VET01-S2. Wayne, PA: Clinical and Laboratory Standards Institute; 2013.

ANONYMOUS (2014): Performance Standards for Antimicrobial Susceptibility Testing; TwentyFourth Informational Supplement. CLSI document M100-S24. Wayne, PA: Clinical and Laboratory Standards Institute; 2014.

COLE, L. K., M. G. PAPICH, K. W. KWOCHKA, A. HILLIER, D. D. SMEAK, A. M. LEHMAN (2008): Plasma and ear tissue concentrations of enrofloxacin and its metabolite ciprofloxacin in dogs with chronic end-stage otitis externa after intravenous administration of enrofloxacin. Vet. Dermatol. 20, 51-59.

COLOMBINI, S., S. R. MERCHANT, G. HOSGOOD (2000): Microbial flora and antimicrobial susceptibility patterns from dogs with otitis media. Vet. dermatol. 11, 235-239.

GIGUÈRE S., J. F. PRESCOTT, P. M. DOWLING (2013): Antimicrobial Therapy in Veterinary Medicine. $5^{\text {th }}$ Edition, Wiley Blackwell.

HARADA, K., S. ARIMA, A. NIINA, Y. KATAOKA, T. TAKAHASHI (2012): Characterization of Pseudomonas aeruginosa isolates from dogs and cats in Japan: current status of antimicrobial resistance and prevailing resistance mechanisms. Microbiol. Immunol. 56, 123-127.

LIVERMORE, D. M., T. G. WINSTANLEY, K. P. SHANNON (2001): Interpretative reading: recognizing the unusual and inferring resistance mechanisms from resistance phenotypes. J. Antimicrob. Chemother. 48, Suppl. S1, 87-102. 
S. Pintarić et al.: Fluoroquinolone susceptibility in Pseudomonas aeruginosa isolates from dogs

MARKEY, B., F. LEONARD, M. ARCHAMBAUlT, A. CULlinANE, D. MAGUIRE (2013): Clinical Veterinary Microbiology. $2^{\text {nd }}$ ed., Mosby Elsevier, Edinburgh, London, New York, Oxford, Philadelphia, St. Louis, Sydney, Toronto, pp. 275-284.

MARTÍN BARASSA, J. L., P. LUPIOLA GÓMEZ, Z. GONZÁLEZ LAMA, M. T. TEJEDOR JUNCO (2000): Antimicrobial susceptibility patterns of Pseudomonas strains isolated from chronic canine otitis externa. J. Vet. Med. 47, 191-196.

McKAY, L., C. D. SCHUMAN ROSE, J. L. MATOUSEK, L. S. SCHMEITZEL, N. M. GIBSON, J. M. GASKIN (2007): Antimicrobial testing of selected fluoroquinolones against Pseudomonas aeruginosa isolated from canine otitis. J Am. Anim. Hosp. Assoc. 43, 307-312.

MEKIĆ, S., K. MATANOVIĆ, B. ŠEOL (2011): Antimicrobial susceptibility of Pseudomonas aeruginosa isolates from dogs with otitis externa. Vet. Rec. 169, 125.

MÜLLER, E., S. HOM (2009): Efficacy of enrofloxacin and marbofloxacin against bacterial isolates from dogs and cats - in vitro resistance study. Prakt. Tierarzt 6, 512-521.

PETERSEN, A. D., R. D. WALKER, M. M. BOWMAN, H. C. SCHOTT II, E. J. ROSSER JR. (2002): Frequency of isolation and antimicrobial susceptibility patterns of Staphylococcus intermedius and Pseudomonas aeruginosa isolates from canine skin and ear samples over a 6-year period (1992-1997). J. Am. Anim. Hosp. Assoc. 38, 407-413.

RIDDLE, C., C. L. LEMONS, M. G. PAPICH, C. ALTIER (2000): Evaluation of ciprofloxacin as a representative of veterinary fluoroquinolones in susceptibility testing. J. Clin. Microbiol. 38, 1636-1637.

RUBIN, J., R. D. WALKER, K. BLICKENSTAFF, S. BODEIS-JONES, S. ZHAO (2008): Antimicrobial resistance and genetic characterization of fluoroquinolone resistance of Pseudomonas aeruginosa isolated from canine infections. Vet. Microbiol. 131, 164-172.

STATISTICA (2014): Statistica StatSoft Inc., v12.5., Tulsa, OK, USA.

STRATEVA, T., D. YORDANOV (2009): Pseudomonas aeruginosa - a phenomenon of bacterial resistance. J. Med. Microbiol. 58, 1133-1148.

ŠEOL, B., T. NAGLIĆ, J. MADIĆ, M. BEDEKOVIĆ (2002): In vitro antimicrobial susceptibility of 183 Pseudomonas aeruginosa strains isolated from dogs to selected antipseudomonal agents. J. Vet. Med. 49, 188-192.

TEJEDOR, M. T., J. L. MARTIN, M. NAVIA, J. FREIXES, J. VILA (2003): Mechanisms of fluoroquinolone resistance in Pseudomonas aeruginosa isolates from canine infections. Vet. Microbiol. 94, 295-301.

WERCKENTHIN, C., E. ALEŠIK, M. GROBBEL, A. LÜBKE-BECKER, S. SCHWARZ, L. H. WIELER, J. WALLMANN (2007): Antimicrobial susceptibility of Pseudomonas aeruginosa from dogs and cats as well as Arcanobacterium pyogenes from cattle and swine as determined in the BfT-GermVet monitoring program 2004-2006. Berl. Münch. Tierärztl. Wochenschr. 120, 412-422.

WILDERMUTH, B. E., C. E. GRIFFIN, W. S. ROSENKRANTZ, M. J. BOORD (2007): Susceptibility of Pseudomonas isolates from the ears and skin of dogs to enrofloxacin, marbofloxacin, and ciprofloxacin. Am. Anim. Hosp. Assoc. 43, 337-341. 
S. Pintarić et al.: Fluoroquinolone susceptibility in Pseudomonas aeruginosa isolates from dogs

Received: 20 January 2016

Accepted: 22 December 2016

\section{PINTARIĆ, S., K. MATANOVIĆ, B. ŠEOL MARTINEC: Osjetljivost na fluorokinolone izolata bakterije Pseudomonas aeruginosa izdvojenih iz pasa istražena dvjema metodama - disk-difuzijskim postupkom i mikrodilucijom. Vet. arhiv 87, 291-300, 2017.}

\section{SAŽETAK}

Pseudomonas aeruginosa značajan je uzročnik velikog broja različitih infekcija u ljudi i životinja koje je teško liječiti zbog visokog stupnja urođene rezistencije ove bakterije. Također, vrsta $P$. aeruginosa vrlo brzo razvija nove mehanizme rezistencije, a više njih se može istovremeno očitovati u samo jednom izolatu što rezultira multirezistentnim fenotipom. Uzimajući u obzir to da na selekciju rezistentnih sojeva utječe pretjerana i neodgovarajuća uporaba antibiotika, osobito fluorokinolona, cilj ovog rada bio je istražiti osjetljivost izolata bakterije $P$. aeruginosa na pojedine fluorokinolone. Disk-difuzijskim i mikrodilucijskim postupkom određena je osjetljivost 90 sojeva izdvojenih iz pasa. Na temelju rezultata obiju metoda, izolati su bili značajno osjetljiviji na ciprofloksacin nego na marbofloksacin ili enrofloksacin i značajno osjetljiviji na marbofloksacin nego na enrofloksacin. Usporedbom ovih dviju metoda, uočeno je da su se rezultati dobiveni za ciprofloksacin podudarali kod $98,9 \%$ izolata, a za marbofloksacin kod $91,1 \%$ izolata. U podudarnosti interpretacijskih skupina dobivenih za ta dva antibiotika nije bilo statistički značajnih razlika. Rezultati dviju metoda za enrofloksacin bili su jednaki kod 76,6\% izolata, a među metodama utvrđena je statistički značajna razlika za ovaj antibiotik $(P<0,05)$. Većina „malih grešaka“ (16 od 20) rezultat je procjene testiranih izolata osjetljivim temeljem rezultata disk-difuzijske metode, a isti izolati testirani mikrodilucijom bili su umjereno osjetljivi. Takvi rezultati upućuju na zaključak da terapija enrofloksacinom temeljena samo na rezultatu disk-difuzijske metode može biti neučinkovita i kao takva može pridonijeti selekciji rezistentnih i multirezistentnih sojeva.

Ključne riječi: Pseudomonas aeruginosa, pas, fluorokinoloni, rezistencija, disk-difuzijski postupak, mikrodilucija 